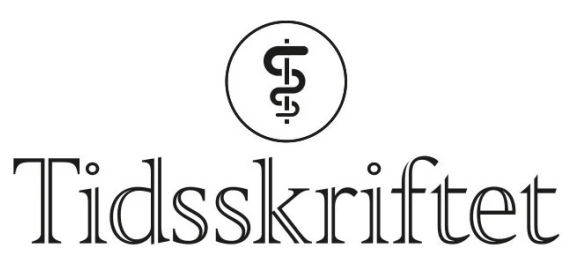

DEN NORSKE LEGEFORENING

\title{
Interessante «sebralinjer»
}

\author{
KOMMENTAR
}

\section{PER HOLCK}

per.holck@medisin.uio.no

Per Holck er professor emeritus, Institutt for medisinsk basalfag, Universitetet i Oslo.

Forfatteren har ikke oppgitt noen interessekonflikter.

I Tidsskriftet nr. 11/2021 har kollegene Kolnes og Jåtun en kort, men interessant artikkel om såkalte «Sebralinjer» (1). Man får imidlertid inntrykk av at dette er et særskilt fenomen ved osteogenesis imperfecta, og at «kvar av de tverrgåande linjene svarer til ein behandlingsrunde/injeksjon med bifosfanat». Jeg går imidlertid ut fra at hver linje representerer knokkelens epifyseskive på et visst alderstrinn, noe som vel forklarer hvorfor "hyppigare injeksjonar gjev kortare avstand mellom linjene», og undres noe over at linjene «også finnast i epi- og apofysane».

Sklerotiske «avtrykk» av knokkelens vekstsoner kan etter min erfaring skyldes flere årsaker, både fysiske og psykiske (르), noe som hadde vært interessant å få belyst i artikkelen. Linjene har ellers vært kjent under betegnelsen «Harris' linjer» (etter den engelske anatomen Henry Albert Harris (1886 - 1968)).

\section{LITTERATUR}

1. Kolnes K, Jåtun BM. Sebralinjer. Tidsskr Nor Legeforen 2021; 141. doi:10.4045/tidsskr.21.0275. [PubMed][CrossRef]

2. Holck P. Harris' linjer. Røntgenfunn på et prehistorisk skjelett. Tidsskr Nor Lægeforen 1984; 104: 1028-31. [PubMed]

Publisert: 22. november 2021. Tidsskr Nor Legeforen. DOI: 10.4045/tidsskr.21.0769

(C) Tidsskrift for Den norske legeforening 2023. Lastet ned fra tidsskriftet.no 26. april 2023. 